\title{
DR. CONSTANTIN HERING EN CHRISTIAAN JOHANNES HERING ${ }^{1}$ ) \\ DOOR
}

FRED. OUDSCHANS DENTZ

Het eeuwfeest der homoeopathische geneeswijze in Amerika, dat een bezoek van eenige honderden Amerikaansche homoeopathen in ons land ten gevolge had, deed de naam van Dr. Constantin Hering naar voren komen, den man, die wordt beschouwd als de grondlegger dezer geneeswijze in Amerika.

Dit feit zou op zich zelf geen aanleiding zijn om in een Westindisch tijdschrift over dezen merkwaardigen man te schrijven, ware het niet, dat hij een aantal jaren in Suriname woonde, een tijd waarin veel wetenschappelijke arbeid is verricht, die in de Nederlandsche literatuur nog weinig bekend is. Bovendien huwde hij voor de eerste maal in Suriname, waar zijn eenige aldaar geboren zoon de stamvader werd van het geslacht Hering, in Suriname nog voortlevend.

Aan beide Herings, vader en zoon, wordt deze schets gewijd, waarbij dankbaar gewag wordt gemaakt van de welwillend verstrekte inlichtingen, welke de familieleden Hering, zoowel in Suriname als in Nederlandsch-Indië, en de autoriteiten in Oschatz (geboorteplaats van Hering den oudere), door bemiddeling van den consul-generaal te Leipzig F. M. Knobel als andere personen in Nederland, en de Vereenigde Staten van Noord-Amerika mij hebben verstrekt.

De familie Hering stamt uit Moravië. De naam werd oorspronkelijk Hrinka gespeld. Later woonden de Herings in Saksen en zij zijn bekend als scheepsbouwers, zeilmakers, bierbrouwers. De vader van den hoofdpersoon van deze schets, Christian Gottlieb Carl Hering, op 25 October 1766 te Schandau geboren, werd aanvankelijk voor predikant opgeleid, maar aanvaardde nimmer dit ambt, wijdde zijn leven aan onderwijs en muziek, werd in 1795

$\left.{ }^{1}\right)$ Wegens plaategebrek kon dit artikel niet in het jubileumjaar geplaatst worden.

Redactie W. I. G. 
conrector en organist van de kerk te Oschatz met den titel van Magister, welke met dien van doctor in de philosophie gelijk staat, in 1811 hoofd van de openbare school te Oberlausitz en professor in de muziek aan het seminarie aldaar. Hij schreef tal van werken over de muziek en zijn kinderliederen zijn tot heden over de wereld bekend. Magister Hering was een alom bekend persoon te Oschatz, waar op nieuwjaarsdag van 1800 Constantin Hering werd geboren, een der kinderen van dit rijk gezegend huwelijk van 8 zoons en 5 dochters. De studie zoowel van de natuur als de wetenschap trok den jongen Constantin aan.

In 1817 werd hij voor de studie der geneeskunde naar Dresden gezonden en drie jaren later naar Leipzig, waar tegelijk vier zonen van den Magister Hering studeerden, die de „vier Heringen" werden genoemd. Ewald, die predikant werd, Karl Eduard, die zich aan de muziek wijdde, Julius de philoloog, die het leven verloor bij het redden van een vriend en Constantin wiens bijnaam als student „Der alte Wisent” was.

Op 23 Maart 1826 behaalde Constantin te Würtzburg met lof den titel van doctor in de geneeskunde met het proefschrift „De Medicina Futura", waarin hij met kracht en groote kennis de theorie van Hahnemann, den grondlegger van de homoeopathie verdedigde.

De aanleiding om de homoeopathische geneeswijze te verdedigen was uit een zeer bijzondere omstandigheid ontstaan. Een groote uitgever had hem nl. uitgenoodigd tegen Hahnemanns doctrine een boek te schrijven, doch de studie van diens toen weinig populaire geneeswijze bekeerde hem als een Saulus, die een Paulus werd. Van een doodelijken tegenstander werd hij een voorstander en verdediger, wiens naam onafscheidelijk als een der pioniers aan de homoeopathie is verbonden. Niet weinig droeg daartoe zijn eigen genezing bij, toen hij bij een lijksectie een doodelijke wond aan een zijner vingers had opgedaan, waartegen geen geneesmiddel hielp, en arsenicum hem redde, zoodat geen amputatie noodig was. „Hahnemann redde mijn vinger en ik geef hem mijn geheele hand, en aan de verbreiding zijner leerstellingen niet alleen mijn hand, maar mijn geheele persoon, ziel en lichaam" waren Herings woorden.

In Mei van datzelfde jaar, werd hij tot leeraar in de wiskunde en natuurwetenschappen aan het Blochmanns instituut te Dresden benoemd en kort daarna ontving hij van den koning van Saksen de vereerende uitnoodiging om als lid van een wetenschappelijke expeditie naar Suriname en Cayenne te vertrekken, waar hij en zijn vriend Weigel de flora en fauna zouden bestudeeren en een verzameling voor Saksen aanleggen. 


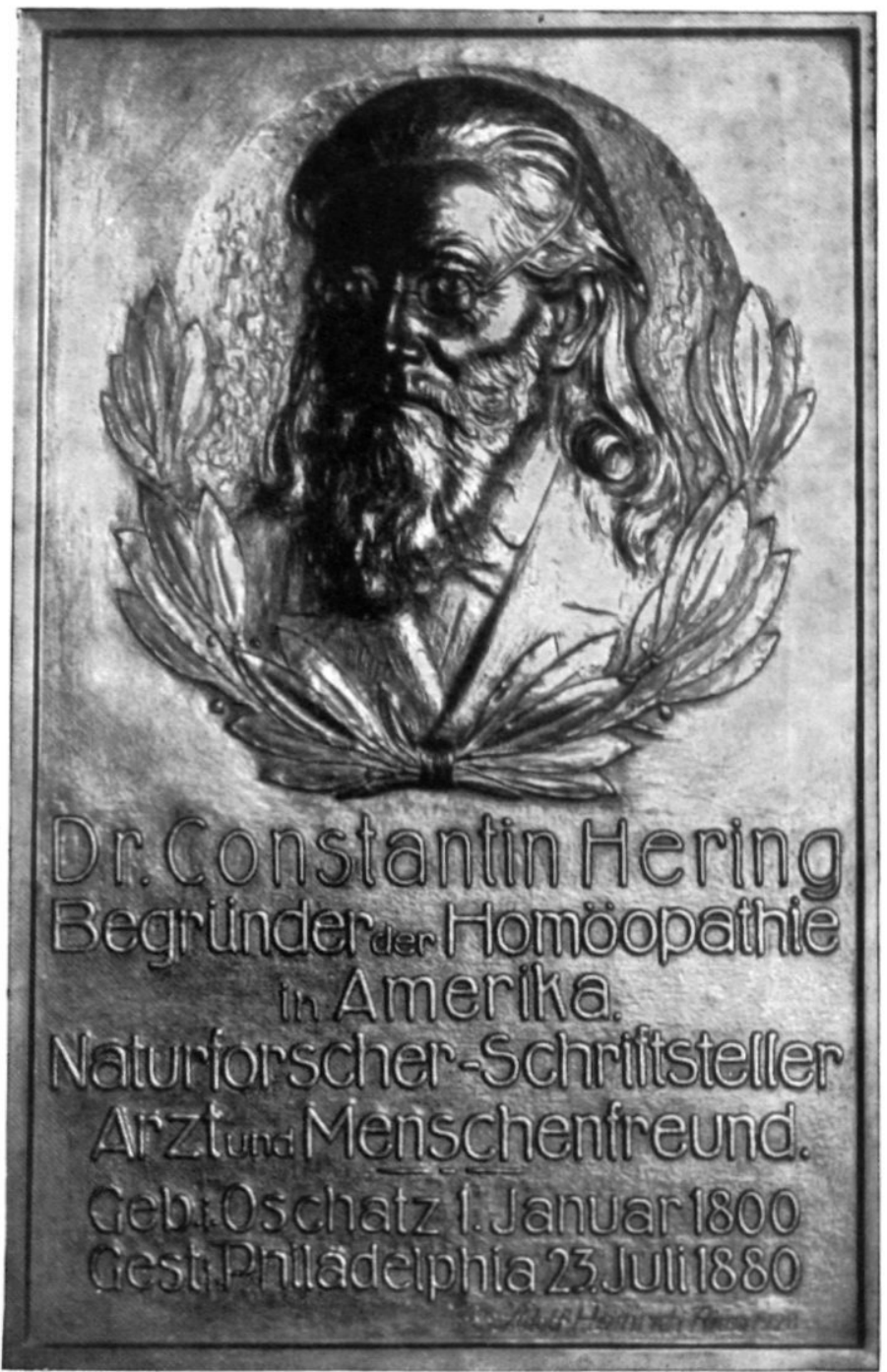

Bronzen gedenkplaat onthuld op 24 Juli 1927 te Oschatz 
In Paramaribo aangekomen kwam hij spoedig met de zendelingen der Moravische Broedergemeente in aanraking, in wier midden hij kwam te wonen en wier vriend en geneeskundige raadgever hij werd. Naast zijn wetenschappelijk werk in dienst van den koning kon hij zijn liefde voor de homoeopatische geneeswijze niet vergeten, waarvoor hij in de kolonie der Duitsche broeders volop gelegenheid had. Verschillende wetenschappelijke artikelen zond hij naar de Homoeopathische Archives, waaraan hij sedert 1825 medewerker was geweest. Tal van nieuwe en belangrijke specimina zond hij naar het Saksische museum en hij hielp zijn vriend Weigel in de bereiding van het herbarium-materiaal, waarvan drie duizend stuks naar Saksen werden gezonden.

Zijn arbeid voor de homoeopathische geneeswijze werd door vijanden onder de aandacht van den koning gebracht, waarop een streng bevel volgde om zijn werkzaamheden alleen te bepalen tot de hem gegeven wetenschappelijke opdracht, waarvoor hij was uitgezonden. Met de keerende post zond Hering verslag van zijn arbeid en diende daarbij tevens zijn ontslag in. Zijn zelfstandige natuur kon die censuur niet verdragen.

$\mathrm{Nu}$ had Hering gelegenheid zich volop te wijden aan de praktijk en zijn genezingen brachten hem vele volgelingen. Een hunner was de Moravische zendeling dr. George H. Bute, die hij van een doodelijke ziekte genas en die hij van patient tot een volgeling maakte. Hering kreeg een groote praktijk en had het vertrouwen van velen, waaronder dat van den Gouverneur, wiens dochter hij genas, nadat andere geneesheeren haar ongenezelijk hadden verklaard. Zijn talrijke proefnemingen beschreef hij in wetenschappelijke artikelen, welke hij naar zijn vriend Stapf ter publiceering zond. Hij bestudeerde de zeden en gewoonten van creolen, mulatten, negers, en Indianen (Arowakken) en in het tropische oerwoud deed hij op 28 Juli 1828 de ontdekking van de geneeskundige kracht van het gif der Ouroekoekoe slang en hij paste met persoonlijken moed tal van proefnemingen op zich zelf toe. Het door hem bereide slangengif werd als geneesmiddel in de Materia Medica opgenomen.

Over zijn proefnemingen met slangengif kunnen wij het volgende mededeelen. In het werk van Lenz ${ }^{1}$ ) lezen wij: op blz. 460 Auszug aus dem Archiv für die homöopathische Heilkunst, herausgegeben von Dr. Ernst Stapf, Band 10, Heft 2. Dr. C. Hering zu Paramaribo in Surinam über das Schlangengift:

„Es war daher, schon früher, ehe ich noch in den Süden gelan-

$\left.{ }^{1}\right)$ Schlangenkunde von Dr. Harald Othmar Lenz, Gotha 1832. 
gen konnte, immer mein Wunsch, dieses berühmte Gift einst dynamisch untersuchen zu können".

Op blz. 463: „Endlich hatte ich denn das Vergnügen den $28 \mathrm{Juli}$ 1828 des Mittags eine, durch den kühnen Jäger zwar halb erschlagene, aber doch noch brauchbare, grosze wirklich gräszliche Giftschlange zu erhalten. Es war Trigonocephălus Lachěsis, deren Bisz noch weit heftiger wirkt, als der Klapperschlange".

Hering beschrijft daarna de uitwerking op hem zelf van het gif dat hij uit de gifklieren van het dier had gedrukt en de symptomen bij verschillende proefnemingen op verschillende dagen.

Zijn dochter schrijft in haar Biographical Sketch of Dr. Constantin Hering ${ }^{1}$ ) dat hij aan het geneesmiddel den naam Lachesis had gegeven.

In Lenz' boek bovengenoemd, lezen wij ${ }^{2}$ ); „Der Kurukuku welche Linné Crotălus mutus, Shaw Colǔber Alēcto, Prinz Maximilian von Neuwied Lachěsis rhombeāta genannt hat, bewohnt die heiszen Gegenden Süd Amerika's".

De naam Lachesis is die van een der drie schikgodinnen, afgeleid van een Grieksch werkwoord, dat zooveel beteekent als „,iets door het lot verkrijgen ${ }^{3}$ ).

Ook volgens de biografische schets van Raue e.a. ${ }^{4}$ ), paste hij het gif op zichzelf toe.

Bij Schlegel lezen wij daarvan nog het volgende ${ }^{5}$ ):

.....,Ce venin est, a l'état frais, un fluide transparant”. ... „Sa nature tient beaucoup de celle du mucus",.... „on peut même suivant Fontana, le prendre à l'intérieur, sans que se déclarent les moindres conséquences facheuses: cette observation cependant a été récemment contredite par les expériences que le Docteur Hering a fait à Surinam sur la nature du venin d'un Crotale muet. Ce voyageur, prenant à differentes reprises des doses diverses de ce poison mêlé avec de l'eau, en ressentait les effets pendant huit jours et plus: ils se manifestaient par des douleurs dans le larynx et dans d'autres parties du corps par une sécrétion multipliée de mucus dans les membranes du nez et de l'oesophage, par une

1) In Mitteilungen des Deutschen Pioniers-Verein von Philadelphia, Viertes Heft, $1907 \mathrm{blz} .7$.

2) Blz. 460 .

s) Zie het artikel van jhr. dr. W. C. van Heurn in de Tropische Natuur van Oct. 1929: Lachesis Puniceus Boie.

4) Biographical Sketch by Charles G. Raue M. D., Calvin B. Knerr, M. D., Charles Mohr. M. D., Rev. William H. Furness D. D.

') H. Schlegel. Essai sur la physionomie des serpens. La Haye 1837, blz. 33 e. v. 
Philos., Medic. et Chirurg. Doctor, ac Profes. sor publicus ordinarius, etc. etc.

Joannes Lucas Schoenlein, Gratiosi Medicorum Ordinis p. t. Decanus, a d

\section{Disputationem}

P r a s ide

Cajetano Textor,

Yhilos. . Medic. et Chir. Doctore, Augustiss. Regi Ba. variae a consiliis aulicis, ac Professore publico ordinario etc. etc.

$$
\text { pro }
$$

summis in Medicina, Chirurgia et Arte obstetricia honoribus rite obtinendis

$$
\begin{gathered}
\text { praenobili, clarissimo ot perdocto } \\
\text { Viro ac Domino } \\
\text { Constantino Hering, } \\
\text { Saxoni, }
\end{gathered}
$$

die XXII. Martii MDCCCXXVI

$$
\begin{gathered}
\text { hora noma matutina } \\
\mathrm{ha} \text { b e } \mathrm{ndam} \text {, }
\end{gathered}
$$

Prorectorem Academiae Magnificum.

Patres conscriptos, omnium ordinum professores, cives academicos, literatos denique et litera-

rum fautores omni, qua par est, humanitate invitat,

W i r c e b ur g i, Typis Caroli Guilelmi Becker, Universitatis Ty. pographi. 


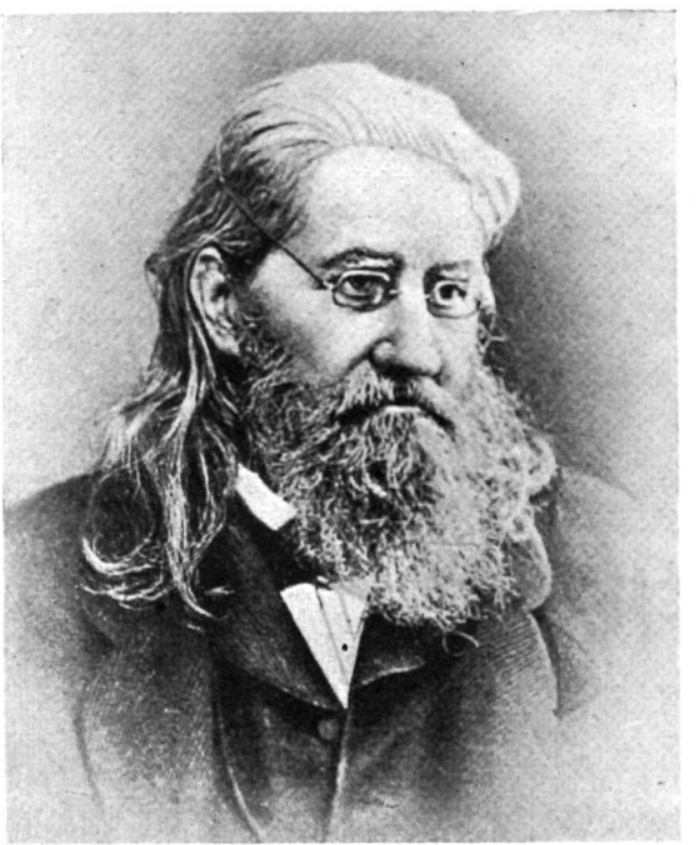

\section{Counaution Hering}

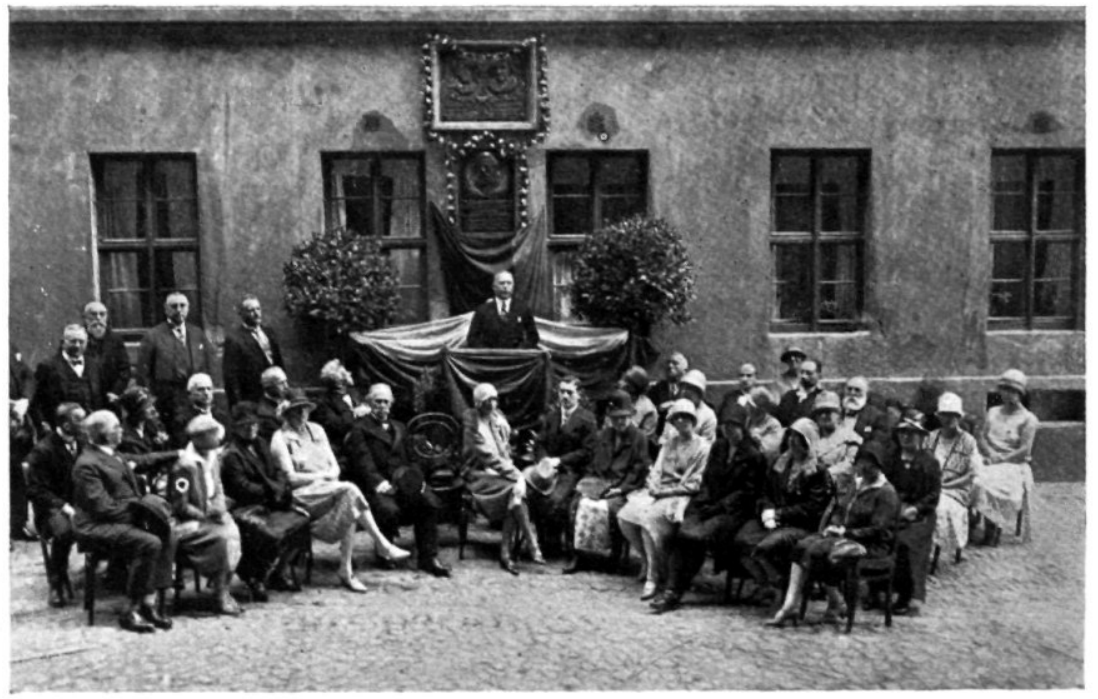

Onthulling gedenkplaat voor Constantin Hering te Oschatz. 
diarrhée fréquante, accompagnée de douleurs dans le rectum, à ces symptones s'en joignaient plusieurs autres assez curieux, dûs à l'influence que ce poison aurait, selon M. Hering, sur les facultés morales".

En verder onder het hoofd: Le crotale muet. C, Mutus $\left.{ }^{1}\right)$ : „Ce grand reptile habite également Cayenne. Esséquébo et Surinam $\left.{ }^{2}\right)$ d'où $\mathrm{M}$. Dieperink nous a envoyé plusieurs et très récemment un individu de 1,83+0,17 de longueur totale. Le docteur Hering qui a fait des expériences intéressantes sur le venin de ce Crotale, s'est servi à cette fin d'un individu long de dix pieds, pris vivant dans les environs de Paramaribo."

Dat de ziekte der melaatschheid Hering's aandacht had, zal geen verwondering baren; hij meende dat de homoeopathische geneeswijze daarvoor heilzaam kon zijn. Juist in dien tijd trad Hahnemann met zijn Psoratheorie op, die veel werd toegepast en ofschoon Hering erkende zijn leermeester niet geheel te kunnen volgen, gaf hij toe, dat de Psoramiddelen bij de behandeling van de lepra nuttig werkten. Hering deed wat hij kon om het lot der melaatschen, met wie hij diep medelijden had te verzachten.

In 1828 vatte hij het plan op in de voorstad Zeelandia een etablissement op te richten voor leprabehandeling en tot dit doel wendde hij zich om vergunning tot den Gouverneur. Het oorspronkelijke verzoekschrift hebben wij niet kunnen achterhalen. Drognat Landré zegt er van in zijn dissertatie: „verzoek van Dr. Hering om een etabliss ement tot genezing der in de kolonie heerschende onreine ziek ten, als lepra, jas, enz. in de voorstad Zeelandia te mogen oprigten". In het verslag der extra ordinaire vergadering van het Hof van Justitie en Crimineele Justitie van 30 Januari 1828, waarin tegenwoordig waren Z. E. de Generaal Majoor Gouverneur A. de Veer als President, de Raad Fiscaal Mr. E. L. Baron van Heeckeren en de Raden F. Beudiker, C. Gollenstede, H. Klind, E. J. van den Bergh, S. M. Klein, G. C. Weissenbruch, Mr. A. G. van der Meer, R. van Rees Az. als secretaris, lezen wij:

De heer Raad Fiscaal dient vervolgens van Consideratien en advys op de Rekeste van den Medicinae Doctor en Chirurgyn Constantin Hering, bij margine dispositie van 23 dezer maand in handen gesteld en tendeerende dat aan hem vrijheid mogt worden verleend, tot het oprigten van een etablissement of hospitaal tot genezing der hier te

1) Ibidem blz. 571

2) Marcgrav, voir Piso, p. 275, a déjà fait mention de cette espèce sous le nom de Çurucucu, q'uelle porte aussi dans tout le Brésil. 
Lande heerschende onreine ziektens als Lepra, jas ${ }^{1}$ ), enz. in de nabijheid der stad, en wel in de voorstad Zeelandia, op het erf bekend sub. Litt. D. No. 23.

Waarop, na lecture van de voormelde consideratiën en advys, door $Z$. E. den Heer Gouverneur aan de vergadering is te kennen gegeven dat hoezeer Z. H. E. G. alleszins genegen is om aan het loffelijk doel van den suppliant bevorderlijk te zijn, Z. H. E. G. echter vermeend dat het daartoe bij Rekest aangeduide verblijf op Combe minder geschikt kan geacht worden dan 's Lands grond Kwatta, welke grond Z. H. E. G. te kennen gaf bereid te zijn om aan den Suppliant tot het bepaalde einde ten gebruike toe te staan, bij aldien hij hetzelve ter bereiking van zijn oogmerk geschikt zoude oordeelen. Gevende Zijne Excellentie verder te kennen, dat hij tot dat einde den Suppliant bij zich zoude ontbieden om denzelven de aangehaalde bedenkingen mede te deelen, ten einde hem in gelegenheid te stellen om 's Lands grond Kwatta te kunnen bezigtigen, waarna $\mathrm{Zijne}$ Excellentie op bekomen rapport van den Suppliant het Hof van het resultaat van dien bekend zoude maken.

Het welk gehoord zijnde is besloten hetzelve Rekest vooralsnog te houden in Advys.

Het verdere verloop hebben wij in de stukken aanwezig op het Rijksarchief niet kunnen aantreffen, maar dat Hering zich op de genezing van lepra heeft toegelegd, is buiten twijfel. Waardeering van zijn collega's kon hij niet steeds ondervinden, zooals blijkt uit het geschrift van den geneesheer A. van Hasselaar: Beschrijving der in de Kolonie Suriname voorkomende Elephantiasis en Lepra (Melaatschheid) ${ }^{2}$ ) waarin hij o. a. schrijft: „Voor eenige jaren verscheen zekere Doctor Hering (uit Saksen) in de Kolonie, belast met een verzameling uit het plantenrijk bijeen te brengen. De Lepra was al zeer schielijk het hoofdpunt zijner aandacht; hij voorspelde zeer vele mirakelen te zullen verrigten. Deze heeft onvermoeid al zijn homoeopatische geneesmiddelen in het werk gesteld, welke bij onfeilbaar dacht, deze ziekte te zullen genezen; hij heeft echter met zijn duizenddeelige geneeswijze even zoo veel uitgerigt, als zijn voorgangers".

Het was in Herings tijd, dat de Lepraverordening van 1830 tot stand kwam, welke met enkele wijzigingen tot 1929 van kracht is gebleven.

Drie jaren nadat Hering den Surinaamschen bodem betrad, sloot hij een huwelijk met Charlotte Kemper, dochter van Juriaan Kemper, die sergeant bij de Jagers in het district Saramacca was en later directeur van den houtgrond „Berg en Dal”. Deze Kemper had in Nederland het diploma van apotheker behaald. Herings echtgenoote was 17 jaren oud en ontviel hem op 13 Juni

2) Jas = Jaws. (Framboesia).

2) Amsterdam, 1835, blz. 65 . 
1830, kort na de geboorte van hun zoon Christiaan Johannes op 28 Aug. 1829 die de stamvader werd van de Surinaamsche Herings.

Het verlies van zijn vrouw en de hoop om een grooter veld voor zijn homoeopathische geneeswijze te vinden deed hem besluiten, na een zesjarig verblijf Suriname te verlaten en het is niet wonderlijk, dat zijn blik zich naar het land der vrijheid richtte. Hering toch dweepte met persoonlijke vrijheid en vrijheid van woord en gedachte, welke in Suriname niet bevredigd werd. Te liever trok hij naar Amerika, nu zijn leerling Dr. Bute, te Philadelphia, zijn hulp inriep bij de aldaar heerschende cholera.

Zijn landgenooten, de Moravische broeders zagen hem ongaarne vertrekken en de gewoonte volgend riepen zij den Bijbel ter hulpe. De tekst welke werd opengeslagen luidde: ${ }^{1}$ ) Wel, gij goede en getrouwe dienstknecht!.... ga in, in de vreugde uws Heeren. Ofschoon met bezwaard hart, geloofden zij in de voorbeschikking en hielpen zijn vertrek verhaasten. Bovendien gaven zij hem tal van voor de reis noodige zaken mede. Teneinde de zendelingen, die hem bij zijn proefnemingen zoo trouw ter zijde hadden gestaan een aandenken te laten, schreef hij, om in noodgevallen eerste hulp te kunnen verleenen zijn „Homoeopathischen Hausartzt", een boekje, dat alom verspreid werd en in 17 talen werd vertaald.

Hering vertrok in het begin van 1833 uit Suriname, zijn zoontje, als te jong zijnde, aan de hoede van de familie Kemper achterlatende en met het voornemen hem zoo spoedig hij zich te Philadelphia had gevestigd, te laten overkomen. Dit geschiedde in 1834; Christiaan Johannes was toen vijf jaren oud.

Het zeilschip, waarmede hij naar Amerika vertrok, was bestemd voor Salem (Mass.) maar moest om water in te nemen en eenige herstellingen te ondergaan, land aandoen op de kust van Rhode eiland, waar Hering na een stormachtige reis in Januari 1833 op den met sneeuw bedekten grond voet aan wal zette te Martha's Vineyard. Hij had geen geduld om per schip verder te reizen en vertrok over land naar Philadelphia, waar hij dr. Bute terugvond, die aldaar de Homoeopathie had bekend gemaakt. Spoedig kreeg Hering een uitgebreide en winstgevende practijk. Het jaar daarna, 1834, hertrouwde hij met Marianne Husmann, dochter van Johann Heinrich Husmann van Hannover in Duitschland, later een der pioniers der Homoeopathie in Missouri.

Een bloedverwant der Husmanns, dr. Wilhelm Husmann, die in Pensylvanië de homoeopathie beoefende, stelde Hering voor

1) Mattheüs 25 vers 21 . 
een school voor die geneeswijze te Allentown te stichten. Op Hahnemanns geboortedag, 10 April 1835 kwam „,The North American Academy of the Homeopathic Healing Art'. tot stand waarvan Hering president en voornaamste leeraar werd. De eerste steen voor het hoofdgebouw werd op 27 Mei 1835 gelegd, waarbij Hering een Duitsche inwijdingsrede hield, met als tekst Washingtons woorden: ,there is but one right way to seek the truth and steadily pursue it".

Maar er kwam van de Allentown Academy niet veel terecht. De bankier die de fondsen beheerde, ging failliet en Hering toog naar Philadelphia terug om daar de praktijk te hervatten. Hij schreef tal van boeken, vertaalde andere, Duitsche, in het Engelsch. In 1840 ontviel hem zijn tweede echtgenoote. Een verzoek van Hahnemanns weduwe, om als opvolger van diens praktijk in Parijs te komen wonen, weigerde hij, evenals verzoeken om zich te Londen te vestigen. Zijn aangenomen vaderland had hij te lief.

Zijn gezondheid en de drang naar het oude vaderland en zijn familie bewogen hem in 1845 naar Duitschland te gaan, waar hij voor de derde maal huwde en wel met Therese Buchheim, dochter van Christian Friederich, officier van gezondheid te Rautzen in Saksen. De onverwachte dood van zijn zwager, die zijn praktijk waarnam, Dr. Hussmann, riep hem plotseling naar Philadelphia terug, waar hij van 1852 tot zijn dood bleef wonen. Hij leidde een ingespannen leven, had een groote praktijk, veel verantwoordelijkheid, en weinig rust, boeken schrijvende over zijn geneeswijze en onderwijzende aan het Hahnemann Medical College, hetwelk hij in 1848 stichtte. Maar ook veel anders had zijn aandacht. Hij schreef novellen, dichtte en componeerde en het gastvrije huis, door velen „Little Germany” genoemd, was dikwijls het middelpunt van Duitsche vrienden, Duitsche feesten en Duitsche muziek. Hering, de vader der Homoeopathie in Amerika, vierde den 23sten Maart 1876 onder groote belangstelling zijn gouden jubileum als geneesheer. Zijn schoonzoon, Dr. Calvin B. Knerr nam hij in zijn praktijk op, teneinde meer tijd te kunnen wijden aan anderen arbeid. Eenzijdig was hij niet. Op 70-jarigen leeftijd stichtte hij een chirurgisch instituut en met dezelfde bezieling stichtte hij ziekenhuizen voor geesteszieken. Hij was een man met groote wilskracht, doorzettingsvermogen en liefde voor den medemensch. De eenvoudige vrome en bescheiden man stierf op 23 Juli 1880, bezig aan de drukproeven van zijn laatste groote werk, het derde deel van "Guiding Symptons" in den ouderdom van meer dan 80 jaren. „Love the Truth because it is Truth and the Good because 
it is Good" was zijn motto. Naar dezen regel had hij geleefd en toen de tijd van scheiden kwam, was hij gereed.

Ziehier hoe hij dacht:

Ideas rule the world.

All new ideas must be received like new born children and cherished tenderly, for on them depends the future.

The thoughts of man develop; premature negative proof, therefore, is harmful.

We must neither accept nor reject a thing without reason.

Houses, wards cities, counties, states! Is not our union built upon the Gothic plan?

Conclusions in science must be drawn consecutively. like links in a chain.

Has anything ever been done in the world without being carried to extremes?

What does not advance, recedes; nothing remains fixed.

The side that hates, loses.

If every physician pondered over his work as much as does a shoemaker over his, more people would get well.

In 1892, twaalf jaren na zijn dood werd in Chicago, het Hering Instituut gesticht. Op 24 Juni 1927 werd een bronzen gedenkplaat onthuld, geplaatst in het huis, waarin hij te Oschatz het levenslicht aanschouwde. Vele afstammelingen, zoowel uit Amerika als Duitschland, waren daarbij tegenwoordig.

Als tweede persoon in dit artikel volge Christiaan Johannes Hering, zoon van Dr. Constantin Hering, die op 28 Augustus 1829 te Paramaribo werd geboren, de eerste Surinaamsche Hering en stamvader van het tegenwoordig in Suriname en in NederlandschIndië levende geslacht.

Hij had een veelbewogen leven en was rusteloos. Ofschoon hij een wetenschappelijke opleiding ontving, eindigde hij zijn ambtelijke loopbaan als belasting-ambtenaar. Hij was een man van veel aanleg, goede talenkennis, die zich voor Suriname zeker verdienstelijk heeft gemaakt.

Op vijfjarigen leeftijd verliet hij Suriname om zich bij zijn vader te voegen, die het jaar tevoren Suriname voor goed had verlaten. Zijn eerste schoolopleiding ontving hij op de Duitsche school te Philadelphia, later op de kostschool der Moravische Broeders te Liditz, om daarna weer naar Philadelphia terug te keeren, waar hij zijn verdere opleiding zoowel in Duitsch als in Engelsch genoot. In 1842 zond men hem naar de Worcester Academie (een 
met de H. B. S. gelijkstaande school). Daar zijn vader hem gaarne tot geneesheer en natuurkundige zag opgeleid, kreeg hij privaatonderwijs in zoölogie en botanie. De wetenschap had zijn belangstelling; echter gevoelde hij zich in geenen deele tot de chirurgie aangetrokken. Toen zijn vader zich in 1844 naar Europa begaf, was het plan hem ter opleiding in de geneeskunde naar Duitschland te zenden, maar eerst zou hij op familiebezoek naar Suriname gaan, om vandaar naar Holland te reizen, waar zijn vader hem zou komen afhalen. Het lot heeft echter anders beslist. Zijn studie beëindigde hij nimmer en hij is voor goed in zijn geboorteland gebleven, is wel meermalen naar de Vereenigde Staten gegaan, maar steeds naar Suriname teruggekeerd.

In 1844 kwam hij met de schoener „Alpin" in Suriname aan, waar hij door zijn oom P. van Assen, luit. kwartiermeester der troepen, die met Elisabeth Margaretha Kemper, een zuster van zijn moeder was gehuwd, werd ontvangen. Na een oponthoud van 14 dagen vertrok hij naar den houtgrond „Berg en Dal”, waar zijn grootvader Kemper directeur was. Van dezen, een liefhebber van natuurkunde, leerde hij het opzetten van dieren en zijn kennis bracht hij al spoedig in praktijk, toen hij in opdracht voor twee natuurkundigen een verzameling aanlegde van opgezette roofdieren, vogels, kapellen en vlinders, bestemd voor een museum in Frankrijk. Hering raakte grondig bekend met het planten- en dierenrijk van Suriname en kwam in aanraking met mannen als Kappler, mr. Focke enz., maar verzuimde gevolg te geven aan den wensch zijns vaders om naar Duitschland te gaan, teneinde zijn studie voort te zetten.

$\mathrm{Na}$ eenigen tijd stelde een vriend zijns vaders, de gouvernements-secretaris S. de Veer hem als surnumerair ter secretarie aan en hier leerde Hering Nederlandsch. Daar hij geen geschiktheid had voor kantoorarbeid en gouverneur Van Raders meer technische talenten in hem ontdekte, beval deze hem aan den inspecteur voor Landbouw, handel en nijverheid, den heer W. H. Lans aan, die hem in 1846 als élève-sucrier plaatste op de gouvernementsplantage "Catharina Sophia" in het district Beneden-Saramacca, waarvan de in de geschiedenis welbekende boschlooper Montecattini ${ }^{1}$ ) directeur was; deze leerde hem de eesste beginselen van suikerplanten en suikerkoken. Hier ving Hering zijn plantersloopbaan aan, hij kreeg verstand van de cultuur van suiker, koffie,

1) Montecatini, die zich met Kappler met een houtvelling en houthandel onledig hield op de etablissementen Montecatini's oord en Albina aan de Marowijne, vestigde zich in 1847 aan de Marowijne. 
cacao, bananen en cochenille. In de rumstijlerij werd hij een meester. Zijn kennis uit Duitsche en Engelsche boeken, handelende over destillatie en fermentage, bracht hij in praktijk en op verscheidene plantages werd hij als deskundige geraadpleegd.

In 1848 riep zijn vader hem naar Amerika terug om zijn wetenschappelijke studiën voort te zetten en in Philadelphia maakte hij dan ook werkelijk daarmede een begin; maar hij zette niet door. Een rijke vriend zijns vaders stelde hem voor in den handel te gaan. Hij gaf de studie op, kocht een zaagmolen en een compleet toestel om rietsap te ontkleuren en was begin December 1849 in Paramaribo terug. Zijn handel leidde echter tot niets en op aanraden van den Amerikaanschen consul, Somer, die op den grond "Cayenne" nabij Paramaribo met rijstplanten was begonnen, kocht hij in 1851 de verlaten plantage „Abigaelslust” aan het Pad van Wanica voor dat zelfde doel en beplantte 50 akkers met rijst. Het jaar daarna gaf hij gevolg aan het verzoek van de heeren A. Dessé en W. Humphreys om op plantage „Kent” een stijlerij op te zetten. Tevens werd hij belast met suikerkoken en deed hij proeven voor het drogen van muscovade-suiker door middel van een centrifugaal apparaat.

Het duurde niet lang, of Hering begaf zich andermaal - in 1855 - naar Amerika, om zijn studien betreffende den tropischen landbouw voort te zetten. De academie van natuurwetenschappen benoemde hem tot lid. In dien tijd schreef hij zijn eerste werk: The Rum Distillers Manual, ${ }^{1}$ ) dat hij aan den heer Humphreys opdroeg. Aan het einde van datzelfde jaar keerde hij naar Suriname terug met een polarisatie-toestel, een compleet laboratorium en de noodige pullen zwavelzuur. Bij aankomst in Suriname benoemde gouverneur Schimpff hem op zeer gunstige voorwaarden tot destillateur op plantage "Catharina Sophia", waar hij met vrouw en kinderen eenige gelukkige jaren heeft gewoond en wetenschappelijken arbeid heeft kunnen verrichten. Hij was gehuwd met Carolina Rosaline von Rieben ${ }^{2}$ ), geb. op 15 Nov. 1833. Zijn proefneming, om met zwavelzuur het gisten van suikerhoudende stoffen te bespoedigen, had goed gevolg en bezorgde hem als blijk van tevredenheid van den Gouverneur een gratificatie van $f$ 100. - . De hoogleeraar Mulder te Utrecht beoordeelde

1) The Rum Distillers Manual, Philadelphia, King and Baird, 1855.

2) Op 28 November 1788 huwde in Paramaribo George Ferdinand Ernst Baron von Rieben, jongman, Luthersch, oud 40 jaren, geboren te Schönhausen, Hertogdom Mecklenburg Strelitz met Carolina Phillippina Emelina Albertina de Borde de Jouy, jonge dochter, 21 jaren, geb. te Paramaribo. 
zijn arbeid zeer gunstig en Hering, voelende het gemis van een boek over de suikercultuur in het Nederlandsch, zette zich aan den arbeid. Het werd gunstig door de professoren Bleekrode en Mulder beoordeeld, opgedragen aan gouverneur C. P. Schimpff en naar de firma W. Nijgh te Rotterdam gezonden om te worden uitgegeven. Om de kosten te bestrijden kreeg Hering een renteloos voorschot uit de koloniale kas van $f$ 1000.- . Het boek verscheen in 1858: De kultuur en de bewerking van suikerriet ${ }^{1}$ ). Bij zijn vertrek uit Suriname schonk de gouverneur hem $f 300$ kwijt en kort daarna kwam de beslissing van den minister van koloniën, dat de schuld van f700.- - hem eveneens werd kwijtgescholden.

Zijn volgende standplaats was plantage „Rustenburg”, waarvan de gouverneur hem in 1861 tot directeur benoemde (ofschoon niet voorgedragen, maar vermoedelijk in opdracht van hooger hand). Hier zou hij zijn wetenschappelijk onderzoek practisch kunnen bevestigen.

Voor Hering was het noodlottig, dat het opperbestuur in 1863 alle gouvernementsplantages in het openbaar deed verkoopen en dat zijn beschermheer, kapitein E. J. Slengaarde, inspecteur der domeinen van de nijverheid en den landbouw, den dienst verliet. Deze verkoop hield verband met de afschaffing der slavernij in 1863. Een bod van Hering op Rustenburg van $f 36000$ werd geweigerd, omdat de verkoop in het openbaar moest plaats hebben en zij bracht dan ook de zeer hooge som van $f 42000^{2}$ ) op.

Hering kocht toen de verlaten plantage „De jonge Bijenkorf” en begon cacao en bananen te planten. Verder pachtte hij de suikerplantage „Vossenburg”. Hier overleed zijn echtgenoote op 30 Augustus 1867. Na het verstrijken van de pacht, kocht hij de plantage „Molhoop" in Boven-Cottica voor $f$ 10.000. Het failliet gaan van de firma Soesman was voor Hering een groote ramp en hij moest zijn plantage verkoopen. Dit was het einde van zijn plantersloopbaan.

1) Gedrukt bij G. J. Thieme, Arnhem, 3 deelen.

$\left.{ }^{2}\right)$ In een oude potlood-aanteekening, voorkomende in een WestIndische Almanak zie ik :De navolgende Gouvernements plantages verkocht den 15 Sept. 1864 hebben opgebracht:

Catharina Sophia . . . $f 131.000$ kooper E. Dessé

Rustenburg . . . . . f 39.500 " Arfaud en Dandleau

Zorg en Hoop ... . . f 35.000 " H. Wright qq Pearson

Frederiksdorp . . . . f 29.500 " J. P. A. Hoeffelman

Ephrata .. . . . . t 3.100 " N. Nielson

St. Germain .. . . $\frac{f 4.000}{f 242.100}$ " T. Noordberg

$f 242.100$ waarvan de venduemeesters I. Sa-

lomons, J. C. Gomperts en I. F. Faverey ieder $\frac{1}{3}$ v. $4 \frac{1}{2} \%$ kregen of $f 3461,50$ 
Bij het inwerkingtreden van het Besluit van 23 Sept. 1871, ter uitvoering van de wet van 19 Juni 1871 Staatsblad no. 71 (Gouvernementsblad no. 10), waarbij eene belasting op het verbruik van gedestilleerd werd ingevoerd (G. B. no. 18), 1 Januari 1872 in werking getreden, bood het gouvernement aan Hering de betrekking van hoofdkommies aan, welke hij aannam. Hij verkocht plantage „Molhoop”. In deze ambtelijke loopbaan heeft Hering verdienstelijk werk verricht. Met bezadigdheid en tact nam Hering zijn lang niet gemakkelijke betrekking gedurende 26 jaren waar, toen hij zijn pensioen nam. Ongeveer elf jaren daarvan bracht hij in het district Coronie door, alwaar hij in 1887 een maatschappij oprichtte tot de bereiding van kokosnootolie en vezelstoffen. Geholpen door zijn chef, den administrateur van Financiën, A. J. baron Schimmelpenninck van der Oye, die commissaris in deze maatschappij werd ${ }^{1}$ ), kocht hij de plantage „Burnside”. Tegenspoed en gebrek aan deelnemers deden de zaak mislukken en zij werd geliquideerd. Hij hertrouwde in 1888 in Coronie met Antoinette Wilhelmina Smit, die nog in leven is en thans den hoogen leeftijd van 95 jaren heeft bereikt.

In 1900 keerde hij naar Paramaribo terug, waar hij voortging met schrijven. Op 77-jarigen leeftijd overleed hij aldaar op $30 \mathrm{Mei}$ 1907 , nalatende twee zoons, (een was geneesheer en een apotheker) en een ongetrouwde dochter, uit het gezin van 6 kinderen van zijn eerste huwelijk.

Behalve de reeds genoemde werken schreef Hering in 1901: Verhandeling over de voedingsmiddelen der kolonie Suriname, haar cultuur en hunne bereiding en over de Surinaamsche vruchten in betrekking tot handel en nijverheid. In 1902: Overzicht van de cultuurgewassen en boschproducten in verband met nijverheid en handel in de kolonie Suriname. In 1903 verscheen: Nuttige palmen der kolonie Suriname. In hetzelfde jaar gaf hij een korte levensbeschrijving van $\mathrm{mr}$. H. Ch. Focke uit. Zijn artikel: De oudheden van Suriname verscheen in de Catalogus der Ned. W. I. Tentoonstelling te Haarlem, 1899. Voor het onderzoek naar de Indiaansche oudheden ${ }^{2}$ ), verricht met steun uit 's Rijks middelen, verwierf hij van $Z$. M. Willem III de zilveren medaille voor

1) Als commissarissen zien wij verder nog vermeld: John Fennely, J. M. de Vries, mr. Henry Benjamins, A. A. Samuels en C. J. Hering. Het kapitaal zou uit $f 100.000$ moeten bestaan.

2) Hering teekende de afbeeldingen op de Timehri-rots in de Marowijne na. De teekeningen zijn in het Rijks Ethnografisch Museum. Zie Sporen van voorhistorische bewoners van Suriname, door J. W. Gonggrijp, W. I. Gids, dl. II, blz. 1. (1920). 
verdiensten ten opzichte van 's Rijks verzamelingen van Wetenschap en Kunst. Zijn inzendingen aan de Internationale en Koloniale Uitvoerhandeltentoonstelling te Amsterdam (Mei-Oct. 1883) werden bekroond met de gouden medaille voor zijn inzending van Indiaansche voorwerpen, en met de zilveren medailles voor een Proeve tot een bibliographie der Kolonie Suriname en voor diagrammen, aantoonende het resultaat der meteorologische waarnemingen, gedaan in de kolonie Suriname en met een bronzen medaille voor zijn Schets van de Cultuur en Fabricage van het Suikerriet in de kolonie Suriname. Veertig jaren heeft Hering zijn weerkundige waarnemingen volgehouden (van 18561896) waarbij hij veel medewerking heeft ondervonden van dr. Dumontier, Chef van het Mil. Hospitaal, door wiens tusschenkomst Hering door prof. Buys Ballot aan het bestuur van Suriname werd aanbevolen om met meteorologische waarnemingen te worden belast en ofschoon dit besluit later werd ingetrokken, is Hering er eenvoudig mede doorgegaan. Zie Meteorologie in de Kolonie Suriname in de Goede Tijding nos. 91 en 92 van 1894. Ook de Encycl. v. Ned.- West.Indië, onder „klimaat”

Vele correspondentschappen vielen hem ten deel. Hij was correspondent van het Bureau Central Météorologique te Parijs, dat hem met een bronzen medaille vereerde, van het Smithsonian Institute te Washington, van het Burlington County Lyceum of History Science, van het Wagners Free Institution of Sciences te Philadelphia en lid van de Academy of Natural Science of Phịladelphia, alsmede eerelid van de Royal Agricultural and Commercial Society of British Guiana.

Zijn studie was gewijd aan de belangen van het land, waar ook eenmaal zijn vader had gewerkt.

Literatuur, voor zoover niet genoemd: Mitteilungen des Deutschen Pionier-Vereins von Philadelphia, Viertes Heft, 1907.

The Hahnemannian Monthly, Philadelphia, August 1880, no. 8.

Leipziger Populäre Zeitschrift für Homöopathie, 60ste Jahrg. 1 Januar 1929, no 1.

Familie aanteekeningen.

December 1929. 